\title{
コンパクトトーラス研究
}

桂井誠

( 東京大学工学部)

( 1986 年 12 月 25 日受理)

\section{Review of Compact Toroid Researches}

\author{
Makoto Katsurai
}

(Received December 25, 1986 )

\section{Abstract}

The compact toroids (CTs) include Field Reversed Configurations (FRCs) and Spheromaks. They are characterized by the simply-connected configuration that requires no external magnet linking with toroidal plasma. This paper presents an introductory review on $\mathrm{CT}$ researches and contains the following chapters ; 1 . Magnetic configurations of CT plasmas, 2. Generations of CTs, 3. The tilt instabilities, 4. The equilibrium and beta values of CTs, 5 . The MHD relaxation of spheromaks in connection with those of RFPs, and 6. Prospects of DTs to fusion reactors.

\section{1. 序 プラズマ磁気閉じ込め方式の分類とコンパクトトーラスの位置づけ}

コンパクトトーラスは磁気プラズマ閉じ込め方式の一種であるが, 30 年の歴史を有する核融合研究のな かでは比較的新しいコンセプトである。今日研究されている代表的なプラズマ閉じ込め装置を分類して相互 に関係づけると図 1 に示すようになる1)。乙の図の中で, 単純 ララーを改良したものとして, その中央部の

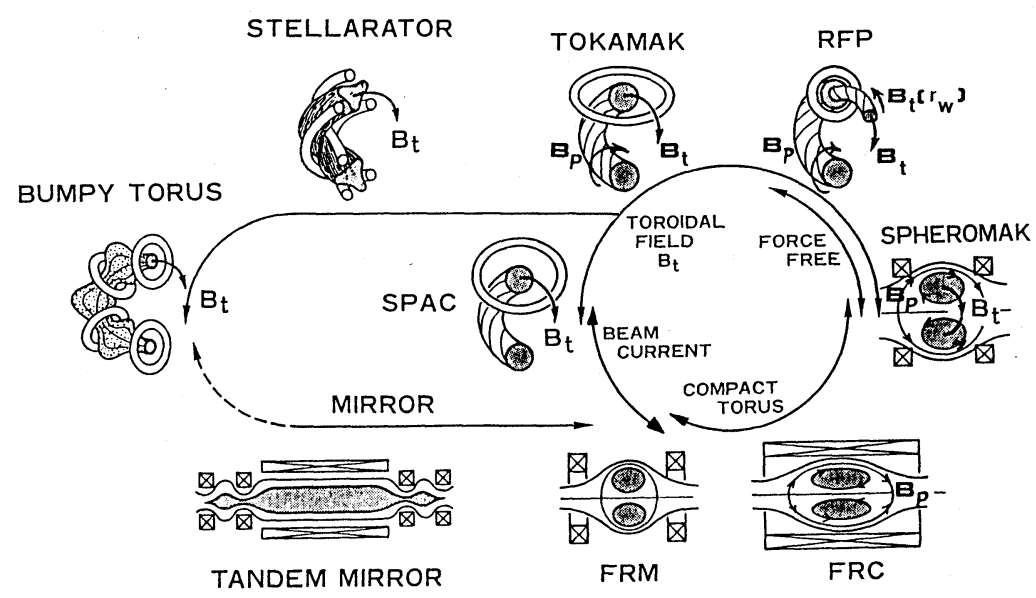

图1.各種磁気閉じ込め方式の相互関連 $B_{t}$ ：トロイダル磁界, $B_{p}$ : ポロイダル磁界

Department of Electrical Engineering, University of Tokyo, Tokyo 113. 
磁界を逆転させてトーラス型の閉じた磁力線を作る方式があり, てれを逆転磁界ミラー（ Field Reversed Mirror - FRM）と呼んでいる。FRMの発生法としては, 外部から粒子ビーム電流を入射するてとが考え られているが、類似の磁界配位を $\theta$ ピンチで発生させるてとが出来て、てれは逆転磁界配位 (Field Reversed Configuration - FRC) と呼んでいる。とのFRCにトロイダル磁界を加えたものがスフェロマックである が，更にそのトロイダル磁界を周辺で逆転させたものが逆転磁界ピンチ（Reversed Field Pinch-RFP) である。通常コンパクトトーラスとはFRCとスフェロマックをさしている。本解説ではコンパクトトーラス の入門として, 全般的な研究動向についての概説を行っているが, より詳しい専門的な内容と文献について は他の解説 ${ }^{2-4)}$ を参照されたい。

\section{2.コンパクトトーラスの発生法}

コンパクトトーラスの磁気配位は出来上がった形をみ ると大変シンプルなものであるが, 問題は如何にそれを 作るかである。

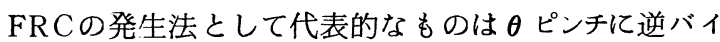
アス磁界を加える方法で，その原理を図 2 に示す ${ }^{5)}$ 。 $\theta$ ピンチコイルの電流を急激に立ち上げるととによって 放電容器内部にそれとは逆方向のトロイダル電流が誘起 され，それと同時に両端部に於ける磁力線の繋ぎ換えが 起てって閉じたポロイダル磁界が発生される。てのとき 加熱されたプラズマは軸方向に磁力線を押し除けて逃げ ようとする。その速度はアルフベン速度 $V_{a}$ で見積もら れ, 従ってプラズマは大略アルフベン時間 $\tau_{a}=L / V_{a}$, $L$ は軸方向の特性長, で逃げようとする。そてでピンチ

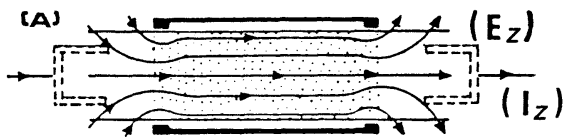

[B]

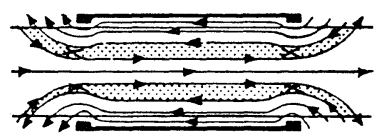

(C)

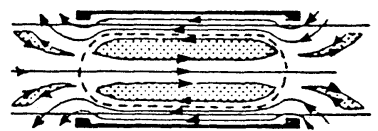

(ㅁ)

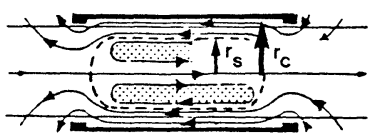

図 2.FRC の生成過程

$\left(E_{z}, I_{z}\right.$ はスフェロマック生成用の電㮔と電流一後述） 電流の立ち上げは $\tau_{\boldsymbol{a}}$ 程度, 通常は数マイクロ秒と早く しなければならない。てのような時間スケールでのプラズマ生成を高速生成という。

とてろで，ピンチを行った段階で安定な FRC配位が生じても，その後数十マイクロ秒たつと， $\theta$ 方向のモー ド数 $n$ に関して $n=2$ の回転不安定が発生してしまう。ての不安定はプラズマ断面が楕円形に変形して $\boldsymbol{\theta}$ 方 向に回転するもので, 時間と共にその振幅が増大して,ついにはプラズマは壁と接触して崩壊してしまう。 この不安定の抑制は長らく FRC 研究の中心課題であったが, 大阪大学グループの努力によって多重極磁界 を用いた安定化法が確立され6)，今日稼動している全てのFRC 装置でその方法が採用されている。表 $1^{7)}$ には代表的な FRC装置とその特性を示す。

他方，スフェロマックの生成法としては上記の $\theta$ ピンチにもとづく方法と，プラズマガン(銃)にもとづく 方法とがある。前者の原理は上記の FRC生成法と類似しているが, 違いは図2（A）に示すように, 両端部 
表 1. 実験中 FRC 装置とその特性

LSX (large s-value experiment) は計画中

\begin{tabular}{|c|c|c|c|c|c|c|c|}
\hline Machine & $\begin{array}{l}\mathrm{Bz} \\
(\mathrm{T})\end{array}$ & $\begin{array}{l}a / L \\
(\mathrm{~cm})\end{array}$ & $\begin{array}{c}\mathrm{Te} \\
(\mathrm{eV})\end{array}$ & $\begin{array}{c}\mathrm{Ti} \\
(\mathrm{eV})\end{array}$ & $\begin{array}{c}n \\
\left(10^{15} \mathrm{~cm}^{-3}\right)\end{array}$ & $\underset{(\mathrm{ms})}{\boldsymbol{\tau}_{\mathrm{E}}}$ & $\begin{array}{c}n \tau_{E} \\
\left(10^{12} \mathrm{~cm}^{-3} \cdot s\right)\end{array}$ \\
\hline $\begin{array}{l}\text { TRX-2 } \\
\text { (Spectra Tech.) }\end{array}$ & 0.8 & $20 / 100$ & 150 & 300 & 3 & 0.05 & 0.15 \\
\hline $\begin{array}{l}\text { OCT } \\
\text { (OSAKA U.) }\end{array}$ & 0.45 & $15 / 100$ & 80 & 80 & 2 & 0.07 & 0.14 \\
\hline $\begin{array}{l}\text { NUCTE-III } \\
\text { (NIHON U.) }\end{array}$ & 1.2 & $16 / 200$ & 100 & 200 & 5 & 0.03 & 0.15 \\
\hline $\begin{array}{c}\text { FRX-C/LSM } \\
\text { (Los Alamos) }\end{array}$ & 0.5 & $40 / 160$ & 150 & 450 & 1 & 0.1 & 0.1 \\
\hline $\begin{array}{l}\text { LSX (Expected) } \\
\text { (Spectra Tech.) }\end{array}$ & $(0.75$ & $80 / 400$ & 300 & 300 & 2 & $\sim 1$ & $\sim 2$ ) \\
\hline
\end{tabular}

に設置した電極 $E z$ をとおして軸方向の $Z$ 電流 $I z$ を同図 $(\mathrm{B})$ と $(\mathrm{C})$ のフェーズにおいてパルス的にながす ことにあって，乙の方法によってFRC発生の際のポロイダル磁界だけでなくトロイダル磁界をも注入する ことが出来る8)。乙れを $Z$ 。一放電法と呼ぶ。とのスフェロマック生成法においてはFRCのように高速生 成する必要はなく, エネルギー閉じ込め時間程度, 通常は数 10 マイク口秒程度と, 比較的ゆっくり生成す るととが出来る。これを低速生成と呼んでいる。

ととろで高速生成を必要とするFRCにおいては， $\theta$ ピンチコイルは1ターンとしてインダクタンスを極 力小さくしてあり, その内側にある真空容器には渦電流の発生を阻止するために石英ガラス等の絶縁物が使 用される。一方同じ $\theta$ 放電を用いるスフェロマックの低速生成においてはインダクタンスをそれはど小さく する必要はなく, 絶縁被覆した数ターンの $\theta$ ピンチコイルをステンレス等のライナーで覆 ってそれを金属製の真空容器の内部に設置す るととも出来る。通常, スフェロマックにお いて $\theta$ ピンチコイルはポロイダルコイルと呼 ばれており，てのような構造のものを内部ポ ロイダルコイル型と呼ぶ。図 3 (A) には乙 の方式を採用した二連構成の T S - 3 装置(東 京大学) を示す ${ }^{9)}$ 。 $Z$ 放電はポロイダルコイ ルを挾んで設置された電極をとおして起てさ れるが、二連であるため (B)図のように多種 の生成モードで各種の実験が出来る。

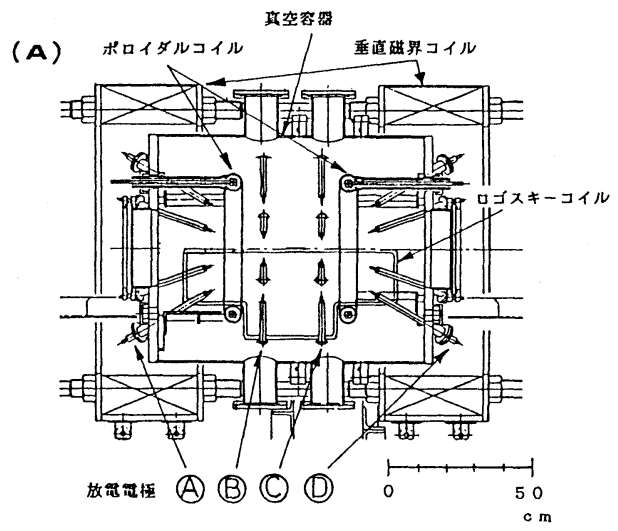

図 3.Z- $\theta$ - 放電を用いた二連式の内部 ポロイダルコイル型スフェロマッ ク装置 TS-3 (A) と各種の生成 モード(B) 
(B)

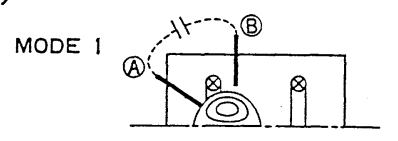

MODE 2

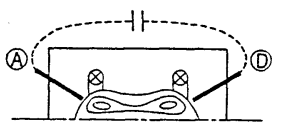

MODE 3

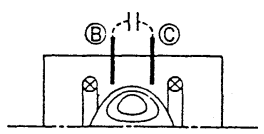

$\operatorname{MODE} 4^{+}$
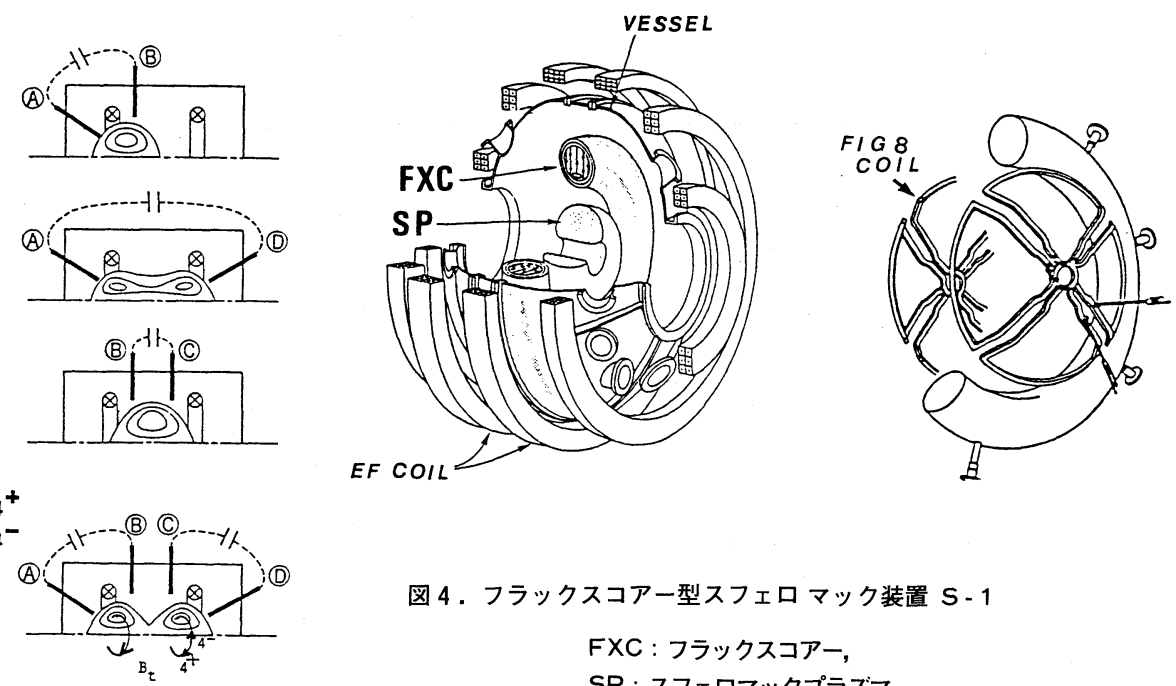

図 4 . フラックスコアー型スフェロマック装置 S - 1

FXC : フラックスコアー,

$\mathrm{SP}:$ スフェロマックプラズマ

MODE 5

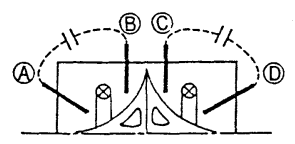

図 3. (B)

上記の $Z$ 放電を，ポロイダルコイル内に別途設置したトロイダルコイルの変流作用を利用して 誘導的に発生 させるととも出来, てれをフラックス・コアー（FXC）方式，あるいは $\mathrm{S}-1$ 方式，と呼んでいる。との 方法はプリンストン大学において考案され, その構造を図 4 亿示す ${ }^{10)}$ 。

他のスフェロマック生成法としてプラズマガンを用いる ものがある。代表的なものとしてアルフベンが考案した磁 化同軸ガン方式の動作を図 5 亿示す ${ }^{11)}$ 。とのガンの出口部 にはラジァル方向の磁界が加壳られている。プラズマの輸 は放電電流によるトロイダル磁束を有しているが, 先端部 より射出するときてのラジアル磁力線を引きずり出してポ ロイダル磁束を作る。通常, 形成されたスフェロマックは フラックスコンサーバ（FC）内に保持される。プラズマ ガンを用いる場合のスフェロマック発生では原理的に高速 生成を必要とするが, 後に述べるへリシティー注入を行う 場合には低速生成あるいは直流動作が可能である。表 $2^{7)}$ には代表的なスフェロマック装置を示す。
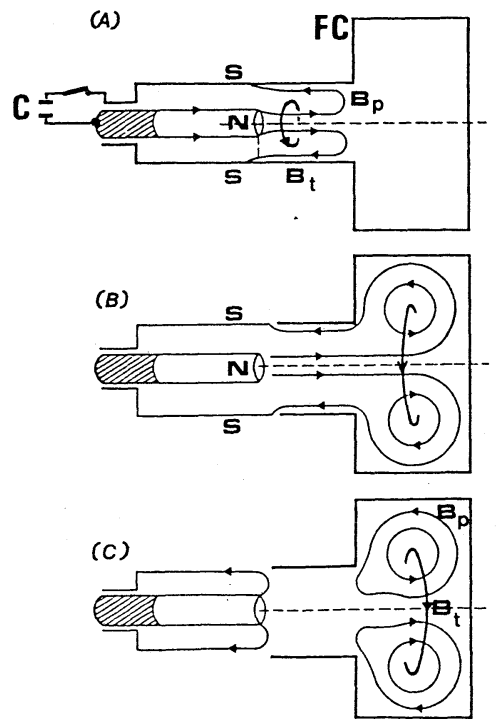

図 5 . 同軸プラズマガン型スフェロマック装置 FC : フラックスコンザーバ 


\begin{tabular}{|c|c|c|c|c|c|}
\hline & $\begin{array}{c}\mathrm{R} \sim \mathrm{a} \\
(\mathrm{m})\end{array}$ & $\begin{array}{c}B t \sim B p \\
(T)\end{array}$ & $\begin{array}{c}\mathrm{Te} \sim \mathrm{Ti} \\
(\mathrm{eV})\end{array}$ & $\left(10^{13} \mathrm{~cm}^{-3}\right)$ & $\begin{array}{r}\tau_{E} \\
(m s)\end{array}$ \\
\hline \multicolumn{6}{|c|}{ Flux-Conserver Type } \\
\hline $\begin{array}{l}\text { CTX } \\
\quad \text { (Los Alamos) }\end{array}$ & $0.4 ; 0.67$ & $\langle$ B $\rangle 0.4 ; 0.6$ & $50 \sim 100$ & 10 & 0.25 \\
\hline $\begin{array}{l}\text { CTCC } \\
\text { (Osaka U.) }\end{array}$ & 0.25 & 0.2 & $20 \sim 30$ & 5 & \\
\hline \multicolumn{6}{|c|}{ External-Field Type } \\
\hline $\begin{array}{l}\text { PS - } 1 \\
\quad \text { (U. Maryland) }\end{array}$ & 0.05 & 0.3 & $10 \sim 15$ & $\sim 100$ & \\
\hline $\begin{array}{l}\text { MS } \\
\text { (U. Maryland) }\end{array}$ & 0.2 & $(\sim 2.5)$ & $(>100)$ & $(\sim 10)$ & \\
\hline $\begin{array}{l}\text { S- } 1 \\
\quad \text { (Princeton) }\end{array}$ & 0.4 & $0.2 \sim 0.3$ & $50 \sim 110$ & $2 \sim 10$ & \\
\hline $\begin{array}{l}\text { TS - } 3 \\
\quad(U . \text { of Tokyo })\end{array}$ & 0.15 & $0.05 \sim 0.1$ & $10 \sim 20$ & $>50$ & \\
\hline
\end{tabular}

PS- 1 , MS, TS-3 は Z - $\theta$ - 放電型, S-1 はフラックスコアー型

\section{3. コンパクトトーラスにおけるティルト不安定}

コンパクトトーラスは，FRCにせよスフェロマックにせよ，トロイダル電流を有しているが，それが自己力 で脹らもうとするフープカを押えるために, 平衡 ( 垂直) 磁界を加える必要がある。ての磁界は外部コイル の電流によって発生されたり, あるいは図 5 のようにフラックスコンザバ内に保持する場合には導体壁内の 渦電流によって発生される。

ところでプラズマ内のトロイダル電流とての平衡磁界発生電流の向きを考えると両者は互いに逆向きであ って, 電流ループを等価磁石に置き換えてみればわかるようにトロイダル電流の輪は平衡磁界の中で逆転し ようとする。とのような不安定性をティルト不安定と呼んでいる。ティルト不安定は,プラズマ表面が不動 で内部のみ回転しようとする内部ティルトと, プラズマ全体が外部磁界を押し除けて回転しようとするグロ 一バルティルトの二種に分類される。後者のグローバルなモードを押えるにはプラズマ表面に接近して安定 化用の 8 の字コイル ( 図 4 参照) 等を設置すれば良い。一方内部ティルトに関してはプラズマ形状がある程 度偏平（オブレート）であれば抑えられるととがわかっている。

スフェロマックについては以上のような直観的な説明と実験結果は良く合っているが，FRCについては 事情は複雑である。今日までのFRC実験によると形状が図 2 に示すように偏平とは逆に偏長であって, 当 然内部ティルトが起っても良さそうなのに全くその兆候が観測されていない。ての原因を単純な MHD 理論 で説明するととはできず,なんらかの運動論的な効果を考える必要がある。今の段階で有力な理論は、イオンの

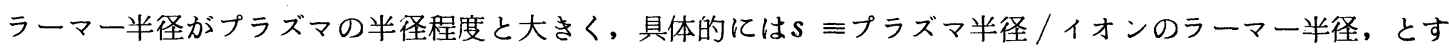
るとき, $s$ の值は 3 程度以下であって，てのためティルト不安定が起てらないというものである。理論によ 
ると $s$ が 3 を越えるあたりから同不安定の成長率は急速に増大すると予想されている。一方, 今日大変低い 值に留まっているエネルギー閉じ込め時間については $s$ の増大に伴って大幅に改善されるのではないかとの 期待がある。実際核融合师プラズマにおいては $s$ 值は 30 程度となる。とのようなわけで少なくとも $s$ が 10 程度のFRCにわいてティルト不安定の動向とエネルギー閉じ込め時間の特性を把握するととが FRC 研 究にとって急務と言える。表 1 中のLSXの主任務はとてにある。

他方, スフェロマックにおいては今のとてろ外部導体に頼ってティルト不安定を受動的に抑制しているが, てれについても外部道体の磁束拡散時間を越える様な長時間にわたっての安定化効果は期待出来ない。さら に導体の冷却とかそれからの不純物混入等の問題がでる。理想的には接近導体を不要とする安定化法の実現 が期待される。てれについてもプラズマに高速の回転を与えるとか高速粒子ビームを入射するなど，なんら かの運動論的な効果を利用する新しい提案が出されている。

\section{4. コンパクトトーラスの平衡とベータ值}

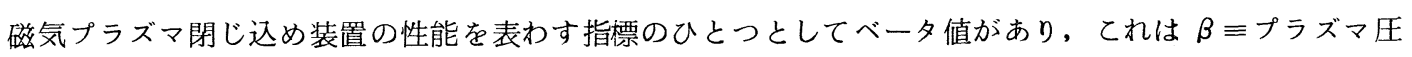
力/磁気圧力, で定義される。乙の $\beta$ 值が 1 亿近いはど閉じ込め性能は高いわけであるが, トカマックなど は $\beta=0.05(5 \%)$ 程度に留まっている。

FRCについては，そもそもプラズマ圧力とポロイダル磁気圧とが釣り合って平衡がなりたっているから 原理的に $\beta=1$ であり, ての観点からは理想的な閉じ込め装置と言える。もう少し詳しい理論によると, 磁 界值としてピンチコイル内側の真空磁界を取り, 圧力としてプラズマ内の平均圧力を取って平均ベータ值 $\beta_{a v}$ を定義すると, 図 2 (D)において示したセパラトリックス径 $r_{s}$, コイル径 $r_{c}$ に対して $X_{s} \equiv r_{s} / r_{c}$ と するとき

$$
\beta_{a v}=1-X_{s}^{2} / 2
$$

が導かれる。今日の実験において $X_{S}$ は $0.3-0.5$ 程度で $\beta a v$ は 0.9 程度と高い。しかし $X_{s}$ が小さいてと はコイル内でのプラズマ径が小さいととを意味しており, 急激な密度の勾配のために粒子閉じ込め時間が著 しく劣化している恐れがある。そてで $\beta_{a v}$ を犠牲にしてでも $X_{s}$ を大きくすれば閉じ込め時間が大幅に改 善出来るのではないかと予想されている。

スフェロマックのベータ值についても多少説明を要する。スフェロマックの平衡とは本来プラズマ圧力ゼ ロの状態でポロイダルとトロイダルの両磁気圧が釣り合った状態であり，後述するようにそれはティラー状態 と呼ばれている。つまり議論の出発となる配位は $\beta=0$ であるが, MHD 安定性の解析によると主に磁気シ ヤーの効果で（スフェロマックに磁気井戸は存在しない）トカマックなみのベータ值， $\beta=0.05$ 程度は実 現可能と考えられている( もっとも今日の $T_{e}$ が数 $10 \mathrm{eV}$ という低温の実験条件では数 $10 \%$ のベータ值が 得られている)。

こてでベータ值という時には磁界值としてプラズマ内部の值を考えているが, スフェロマックにおいては 


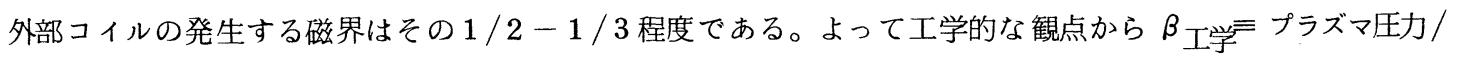

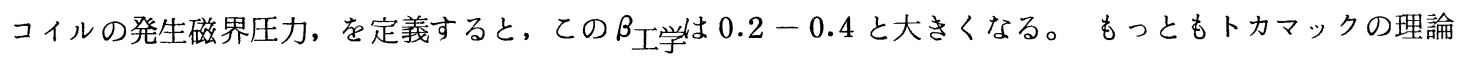
で知られているように, 電流分布の制御をおてなうと第二安定領域が出現するなどしてべータ值はもっと高 い值が実現されるかもしれるい。ただしてれは パワー $(W)$

今のところ単なる憶測である。

とてろでトカマック, ステラレータ(ヘリカル系) ミラーなどでは, 主閉じ込め磁界は外部コイルに よって発生されるのに対して,コンパクトトーラス とかRFPなどではそれはプラズマ電流によって発 生される。そてで後者においては配位形成時にプ ラズマ加熱エネルギーのみならず磁気エネルギ

一をも同時に注入する必要がある。

その磁気エネルギーは大略熱エネルギーの

$1 / \beta$ であるから，それに見合う量の初期エネ ルギーの注入を必要とする。コンパクトトーラ スでは,ほかの方式に比してマグネットが単純 になった見返りとして, 複雑かつ大容量の配位 生成用電源を必要とする。

従来提案されてきた各種核融合炉に付随する 電源の容量を示したものが図 6 である。図中

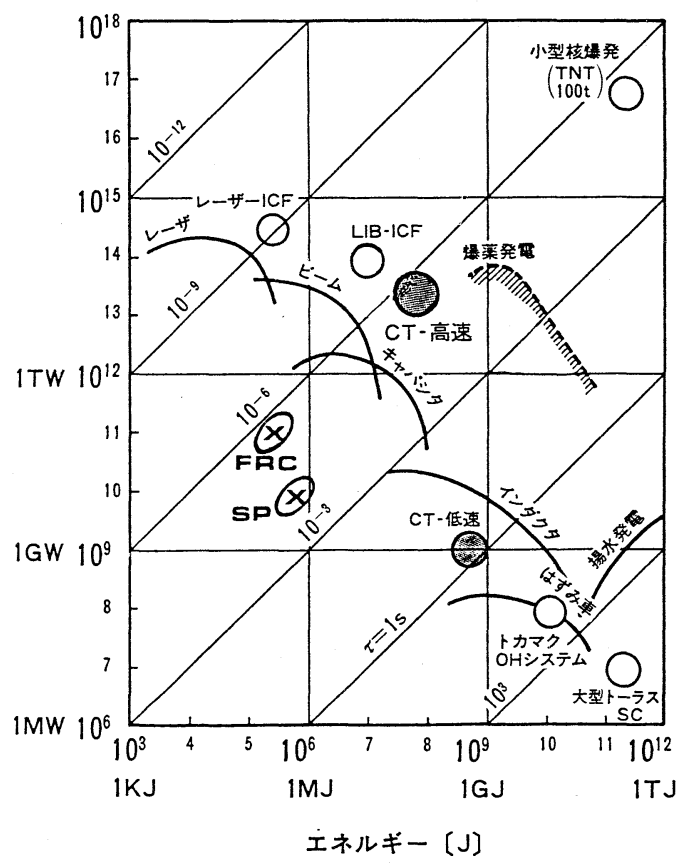

図 6. 各種の核反応プラズマ閉じ込め装置に必要な電源 容量の概略, 及び各種電源の技術的, 経済的限界 の概略, X は今日の FRC とスフェロマック (SP) 電源。

の $\tau$ は注入時間すなわちパルス幅であって, 現在のコンパクトトーラスに対する值をX印でしめす。同図に は炬規模での值も示してあるが, 技術的, 経済的実現性の観点からは高速生成の適用には疑問が持てれてい る。そてで特にFRCに対しては実用的な低速生成法を確立する必要があり，例えば $\theta$ ピンチを同軸構造に する( ワシントン大学)，少量の $Z$ 電流をながす (日本大学) 等の研究が行われている。

\section{5. スフェロマックのMHD的ダイナミックス}

外見から眺めるとスフェロマックはFRC と同じ仲間に扱われるが，配位形成及び維持の面からみるとそれ はむしろRFP（逆転磁界ピンチ）と親戚関係にある。

スフェロマックとRFPにおけるプラズマの力学的平衡状態においては，プラズマ圧力が無視できるゼロ ベータの単純な場合, プラズマ電流に加わる磁気力は局所的にゼロでなければならない。つまりあらゆる場 所で $\boldsymbol{j}(\boldsymbol{r})=\boldsymbol{a}(\boldsymbol{r}) \boldsymbol{B}(\boldsymbol{r})$ となるが, とてで安定な平衡状態はエネルギー最小状態であるとと,およびへ リシティーとよばれベクトルポテンシャルと磁界との内積の体積積分が恒量であるとと, を条件に加えると 
$a(\boldsymbol{r})=a$ : 場所によらない一定值，となるととが導かれる。

てのような状態がティラー状態と呼ばれるものである。て の状態を求めてみると, 上記の条件によりヘルムホルッ型の 方程式が導かれ，その基本解は円筒座標 $(r, \theta, z)$ にたい してベッセル関数を用いて解析的に求めるととが出来る。そ のグラフを示すと, 図7 の様になる。同図において $B_{z}$ ( ト ーラスではトロイダル磁界）＝0の位置に壁があるものがス フェロマックであり, $B_{z}<0$ の位置に壁があるものが

RFPである。通常, RFP 理論では壁の位置に応じて定まる 一つの状態を, 次式で与えられる $F$, 二つのパラメタを用 いて表わす ${ }^{11)}$ 。すなわち壁の半径を $r_{w}$, 断面内での $B_{z}$ の 平均を $B_{z, a v}$ とするとき

$$
\begin{array}{ll}
F=B_{z}\left(r_{w}\right) / B_{z}, a v & (\text { 逆転係数 }) \\
\Theta=B_{\theta}\left(r_{w}\right) / B_{z}, a v & \text { ( ピッチ角 })
\end{array}
$$

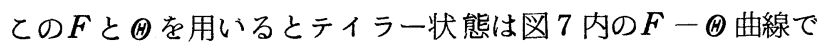
表わされ， $F=0$ の点がスフェロマックであり $F<0$ の点が RFPである( @があまり大きくなると円筒配位からへリカ ル配位へと転移する）。以下話を単純化して基本的な考えを 説明しよう。
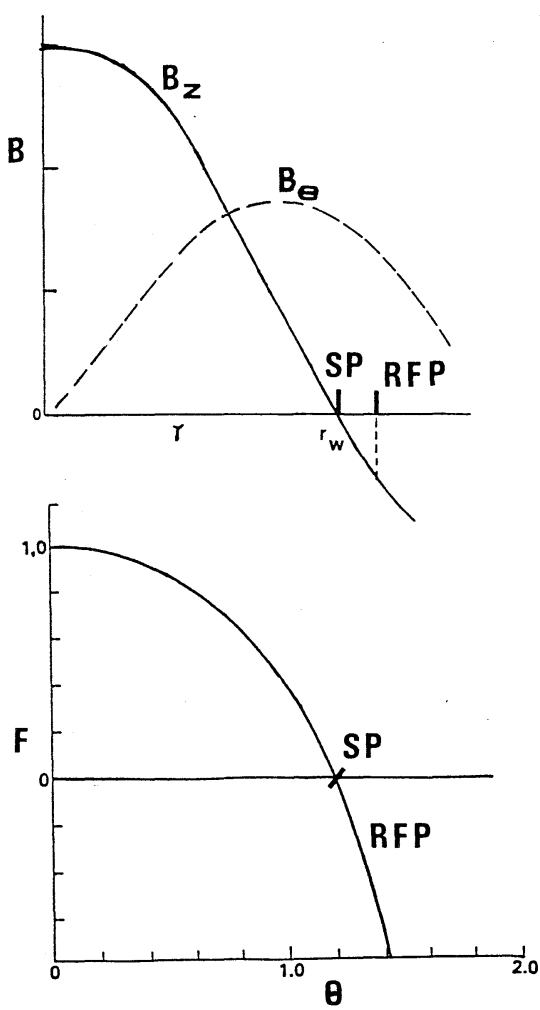

図 7. 円筒プラズマにおけるテイラー状態

(A) 磁界分布, $F-\theta$ 線図

実際のRFP装置においては壁 ( シェル) が $\theta$ 方向に短絡回路を形成しており, 初期に注入したトロイダル 磁束 ( 円筒モデルでは $z$ 方向磁束) が保存される。一方スフェロマックにおいては中心対称軸に沿って外部 導体が存在しないから上記の円筒モデルにおいて壁は $\theta$ 方向に電気的に切れており, 壁の内部には $\theta$ 方向の 電流は流れるてとは出来ない。よって壁の内側で $B_{z}=0$ で $F=0$ のスフェロマックが形成される。スフェ ロマックとRFP とではアスペクト比が大きく違うが, それ以上にポロイダル方向（ $\theta$ 方向）に導体壁が オープンかクローズドかというととに本質的な違いがあって，てれが両者のMHD的振舞いに大きな影響を 及ぼしている。

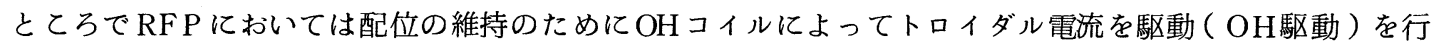
うが, 本来てれによって直接的に維持されるのはポロイダル磁界 $B_{\theta}$ のみである。しかしながらポロイダル 磁界の一方のみが維持されるとティラー状態での $B_{z}$ と $B_{\theta}$ との関係が崩れ, 平衡状態からはずれてしまう。 こうなるとプラズマ内部になんらかの不安定性が発生して, それが逆転構造を有するトロイダル磁界 $B_{z}$ を 維持する。この結果, $B_{z}$ と $B_{\theta}$ の関係がいつも自動調整されてテイラー状態が維持される。 
スフェロマックの発生においてもテイラー状態に向かおうとする緩和過程が機能する。例えば $Z-\theta$ 一放 電を用いる場合には, $Z$ 一放電用と $\theta$ 一放電用のキャパシタバンク充電電圧 $V_{z}, V_{\theta}$ の関係によらず, 発生 したスフェロマック内のトロイダル磁束とポロイダル磁束（あるいはそれと比例するトロイダル電流 $I_{z}$ ) の比は大略一定值になってしまう(図8 亿 TS - 3 装置での結果を示して置く ${ }^{13)}$ )。乙れはプラズマ生成時の 磁束注入条件によらず, 落ち着き先の平衡状態ではティラー理論に従って磁束関係が幾何学的な量のみによ って定まっているととによる。OH駆動を行った場合には，RFPではトロイダル全磁束は保持されるがスフェ

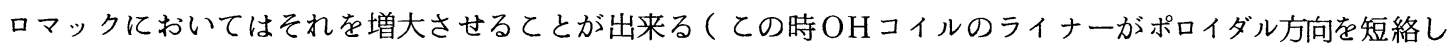
ない様に注意する）。

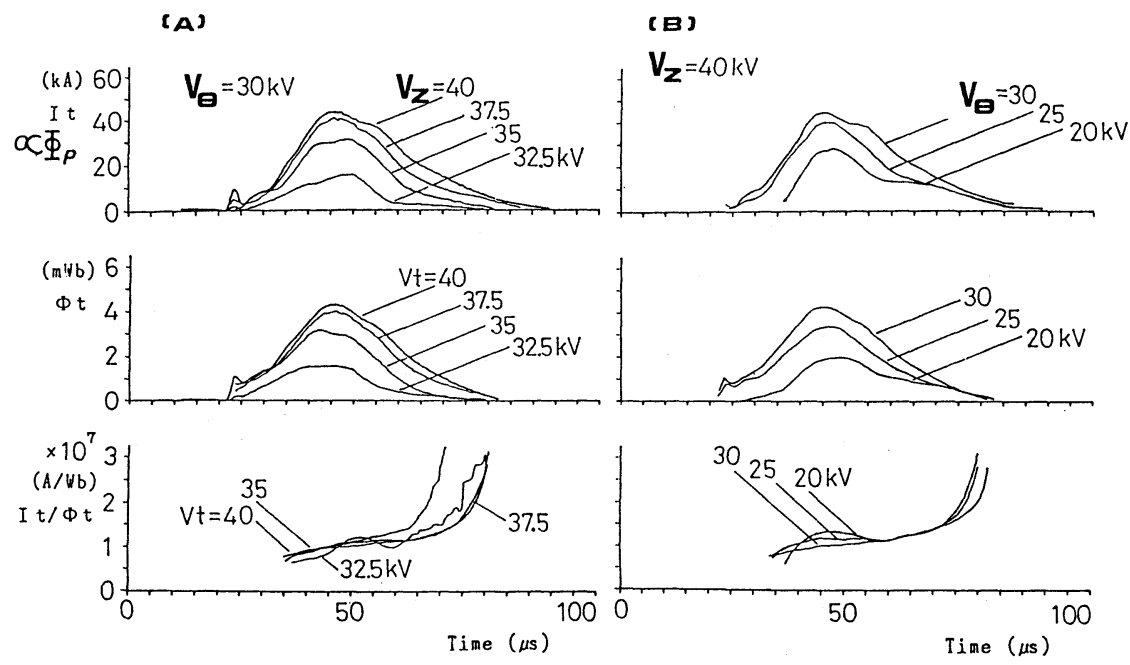

図 8 ．スフェロマック生成時におけるトロイダルとポロイダル両磁束の相互調整

今日ではティラー状態に向かう緩和過程がどのような物理機構によっているかについて, ある程度解明が 進んでいる。目下実験されているような低温プラズマにおいては, 理論的にも実験的にも, 比較的モード数 が低い単一あるいは複数のヘリカル状のキンク不安定がそれに関与しているてとが明らかにされている。て れとは別に乱流的なダィナモ効果で緩和が起てっているのではないかという説もあり, 特にKeVを越えるよ うな高温プラズマにおいてはそれが支配的となる可能性も指摘されているが, 実験的にてのような乱流理論 を確認するととは大変であり, 明快な結 論に到達するととは困難であろう。

とてろでとの緩和過程を利用してスフ エロマックの定常維持を実現しょうとす る提案がある。一つの方法は図 9 亿示す

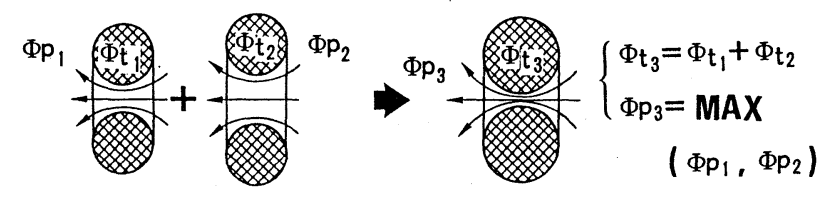

図 9. スフェロマックの合体現象 ように合体効果を用いるものである。同 
方向のトロイダル電流を有する二つのスフェロマックは互いに引き合い一つに合体する。とのとき軸対称性 が保たれているとポロイダル磁束 $\Phi_{p}$ については大さい方の值が維持されるのに対して, トロイダル磁束 $\Phi_{t}$ に関しては足し合うととにする。すると両磁束の比が一定であるティラー状態が崩れるから緩和が起てり, トロイダル, ポロイダルの両磁束ともが増えたスフェロマックに成長する。てのような合体効果を繰り返し おてなうことによって磁束の抵抗減衰を補ったり, あるいは磁束を增大させるととが出来る。

合体の繰り返し率を上げた極限としてスフェロマックの直流維持が実現される。具体的には同軸プラズマ ガンによるスフェロマック発生において直流(実際には長パルス) で放電を行うと図 5 (B) の状態において 定常的にスフェロマックが維持出来る。ての方法はへリシティ一注入法と呼ばれているが, 背景にある物理 は上記の緩和過程である。そのほか, 初め RFPに対して提案された F $\theta$ ポンピング法という方法もスフェロ マックに適用可能であるが，同法の有效性については最近問題点が指摘されている。

以上述べた様にスフェロマックにしろRFPにしろ,ティラー理論に基づく MHD的緩和過程につてはか なり解明が進んできたと言える。そして理論で予測されるようにプラズマはテイラー状態に向かって自己緩 和を行ない，外乱があってもティラー状態を維持しょうとする自己秩序維持の能力を有している。

しかしての緩和過程とは内部の熱エネルギーを吐き出す過程であってエネルギー閉じ込めには障害となる。 今日スフェロマックにしろRFPにしろェネルギー注入効率が低く期待したはど温度が上がらないのは紸和 過程が激しいためとも考えられている。積極的に緩和過程を利用するてとと, 十分なエネルギー閉じ込め時 間を確保するとととが高温領域において旨い具合に両立するのか否かを研究するととがスフェロマック及び RFP 研究にとって最大の課題である。

\section{6. コンパクトトーラス核融合炉の課題}

通常, 核融合炉の概念設計研究にわいて強調されているてとであるが，核融合炉の大きさは，プラズマ閉 じ込め性能がある程度確保されていれば, その物理とは関係なく, プラズマと対面する容器内壁, 即ち第一 壁, の壁負荷（単位面積当たりの通過パワー）に関する制約によって決められてしまう。

現代の材料工学のレベルから達成可能と考光られている壁負荷の值は $10 \mathrm{MW} \cdot \mathrm{Y} \mathrm{r} / \mathrm{m}^{2}$ 程であって, 仮に $2 \sim 3$ 年ごとに交換するものとすれば, 瞬時的な值として許容される最大壁負荷は $4 \mathrm{MW} / \mathrm{m}^{2}$ 程度となる。 そてで実用炍レベルとして熱出力を数 GW として規模を概算すると, 炉の大きさは同じ出力規模の 軽水炉 （ PWR）の大きさに比して格段に大きくなってしまい, 取りたててコンパクトトーラスのみがコンパクト になれるわけではない。核融合师が PWR並の規模になるためには壁負荷が $15-20 \mathrm{MW} / \mathrm{m}^{2} も$ 必要で, この場合には第一壁を数筫月単位で交換するととを余儀なくされる。

こてからは議論が別れるとてろであって, 従来のトカマックなどの低ベータ炬心ではもともと出力密度が それはど上げられないのであるから, 壁負荷としても $4 \mathrm{MW} / \mathrm{m}^{2}$ 程度以下とするととが当然とされてきた。 この場合は軽水炬と比較しての経済性の議論は棚上げされるととになる。 
一方 FRC とかRFPなどの高ベータ炉心開発の可能性が有るものは出力密度も上げられるから，20MW/ $\mathrm{m}^{2}$ もの壁負荷を採用して軽水炉並のコンパクトさを壳りものとするととが強調されてきた。ての時は第一壁 の激しい劣化とか頻繁な交換に関わる諸問題については目をつぶっていた。コンパクトなる呼び名は米国に おいて後者の立場から付けられたわけではあるが, $20 \mathrm{MW} / \mathrm{m}^{2}$ という様な壁負荷を採用するてとについて は，材料関係専門家から困難を指摘する意見も強くあまり学術的な命名とは言いがたい。

コンパクトトーラス炬は，その大きさをそれほどコンパクトにするととは出来ないとしても，その魅力が なくなるわけではない。特に炬構造がトーラスよりも単純であるてと,プラズマを平衡を保ったまま移動さ せるととが出来て発生部と核反応部とを分離できるとと, 最近ますます重要性が強調されているダィバータ の組み込みが簡単であるてと, 等の特徴はユニークである。それにもまして FRCに代表される高べー夕装置 はDD炬などのアドバンストフュエル炬へと発展される期待がある。しかし，問題はエネルギー閉じ込め時 間のスケーリングである。なぜなら，いずれの閉じ込め方式でもべータ值が高くなるとエネルギー閉じ込め時 間 $\tau_{E}$ が劣化する傾向にあり $\mathrm{FRC} と ゙ の \tau_{E}$ は大変低いレベルに留まっているからである。同じ $\left(n \tau_{E}\right)$ 值を 達成するにも $n$ が大きく $\tau_{E}$ が小さいとそれだけ加熱電力が大きくなってしまい, 電源技術, 冷却技術のは うからの制約によって炬としての実現性が少なくなる。低い值に留まっている $\tau_{E}$ を改善する可能性として, $\mathrm{FRC}$ 亿関しては $X_{s}$ と 值の増大, スフェロマックについてはMHD 緩和の抑制, 等があげられるが,それ 等の有効性を確認するととは今後の研究課題である。

\section{参考文献}

1) 桂井 誠：日本原子力学会誌 Vol. 27, No. 10, p. 885 (1985).

2) 野木靖之：核融合研究 Vol. 49, No. 6 p. 551 (1983).

3) 大井 他：電気学会プラズマ研究会資料, EP-86-36,12月 (1986).

4) "Special Issue on Compact Toroids": Fusion Technology, Vol. 9, No. 1 (1986).

5) A. L. Hoffman, et al. : Fusion Technology, Vol. 9, p. 48.

6) S. Ohi et al. : Phys. Rev. Lett., Vol. 51, No. 12 p. 1042 (1983).

7) 関口 忠: 第11回 IAEA 核融合国際会議 Summary talk on alternative Concepts. (1986).

8) H. Bruhns, et al. : Phys. Fluids, Vol. 26, No. 6 p. 1616 (1983).

9) 桂井 誠 他 : 電気学会論文誌, 予定 (1987).

10) A. Janos and M. Yamada : in Ref. [4] p. 58.

11) W. C. Turner et al. : Phys. Fluids, Vol.26, No.7 p.1965 (1983).

12) H. A. B. Bodin and A. A. Newton : Nuclear Fusion Vol.20, No.10, p.1255 (1980).

13) Y. Ono et al. : Submitted. 